\title{
THE HAZARAS AND THEIR ROLE IN AFGHANISTAN By Rauf Zeerak
}

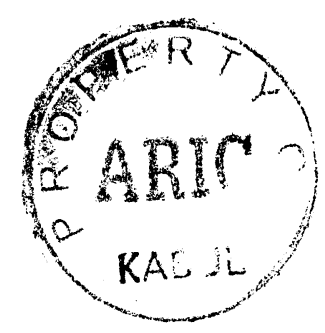

Introduction

The history of Afghanistan is a very tragic one in so many ways. Afghanistan is one of the most indigent and impoverished nations of the world. It is one of the most war-torn, most ravaged, and most besieged of all nations. Furthermore, it has been overwhelmed by invasions, external pressure and internal turmoil ever since before the time of Alexander the Great. The people of Afghanistan have endured more than most of the population of the world. As the situation in Afghanistan has been changed as the weapon on them which has been used has also been changed also. For instance, the weapon has changed from sword and arrow to the latest missile which had been used to bring Russian jets down almost every day during its last three months of invasion.

Afghanistan historically has been a buffer state where it has been a link between Central Asia, the Middle East and the Indian sub-continent. Afghanistan is homeland to four major ethnic groups, which equally have participated, in the country's political history and economic development: this depiction is in bleak contrast to the word Afghanistan that refers only to the Pashtun (Afghan) ethnic group. For instance the word stan in Farsi means "the land of," so Afghanistan means the land of Pashtun. Afghanistan's turbulent history is in great part due to the maneuverings of the machinations of the politically prevailing class in the Afghan policy, which rutted one ethnic group against the other in order to maintain its decree and maintain its class interests. This policy has undermined national unity and vulnerable means of economic development since the country gained its independence from the British Empire in 1919.

Beginning in the 1800s internal affairs of Afghanistan became dramatically provoked by the escalating intervention by two new imperialist powers, the British Empire and Czarist Russia. The British were increasing and consolidating their colonial holdings on the India sub-continent, and were looking at the Hindu Kush mountains of Afghanistan as a natural barrier to prevent invasion by rival imperialists. On the other hand, the Russians, for their part, were expanding south and east, swallowing up several formerly independent sultanates and emirates in Central Asia. Mostly, the two great powers got busy in a race for Afghanistan, and their wicked seizures of land, such as overthrowing native government and hastily interfering into the affairs of the remaining independent states in the region which became known as "the Great Game."

One of the major differences was the issues of sectarian which divided the country. Although the Soviet occupation of Afghanistan (December 1979-February 1989) relegated the question of ethnicity to a secondary position then to that of Islam, however after the establishment of an Islamic state in 1992 various ethnic groups have fought each other trying to establish its domination. All of a sudden, the character of the war has been transformed from Islamic elemental to that of ethnic nationalism, which all sides alluring their own ethnic group to rally behind their own chiefs. The main focus of this article is to study the political alteration of the Hazara people and examine how Hazaras began to shift from religious perspective to Hazara nationalism, inquiring about the role of Hazaras traditional leaders and the people who supported the leadership, but first I give an overview of Hazara origin and theory of autochthonicity by respected scholars.

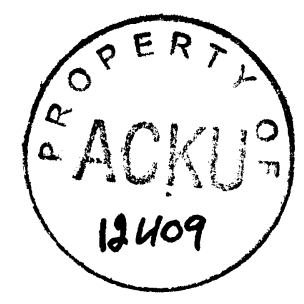


The Hazaras

Hazaras are one of the oppressed and dispossessed national minority ethnic groups of Afghanistan. They inhabit for the most part in Hazaristan or Hazarajat, a landlocked region which includes several provinces in the central part, which comprises the mountainous central areas of Afghanistan. The mountainous terrain is well reflected in the special geographical terms found in Hazaragi Dialect which are the best indication that influence their characteristics on the social and cultural organization of the Hazara people:

Tagau: narrow plain between two mountains, with a river with wide banks, and small valleys, e.g. Taguau-e Barg and Tagau-e Kalanday.

Jolgah: a small lake made up of several rivers, e.g. Jolga-e Hilmand, Jolga-e Golkhar.

Qoal: narrow valley, e.g. Dozd, Qoal-e Lurah.

Goabi or Nau Chah: opening created by floods, e.g. Qoabi-e Choknah, Qoabi-e Dawolat Pai. Navah or Nau: wide valley covering several small Qoals, e.g. Navah-e Mish, Navah-e Baghiran, Nau Jo, and Dara Nau.

Toghai: stretch of verdure on the bank of a river, e.g. Toghai-e Tabargho.

Qash: mountain spring surrounded by bushes (Qash also mean 'eyebrow' in Hazaragi)

Olum: ford, the shallow part of a river, where the people cross, e.g. Sar-e Olum and Perakh Olum. Kandaloo: foot of a mountain or hill.

Aska: mountain plains bordered by rivers on three sides, e.g. Sar-e Aska, and Dahan-e Aska (Gharjistani, 1988: 161-2).

Hazarajat has very distinctive boundaries. For instance, a traveler knows exactly when he/she enters Hazara territory. The boundary markers for the Hazara Ethnic group stimulate traits to distinguish them from the rest of Afghanistan's populations. The reason is that their strongly Mongoloid Turkic appearance makes it easier for all Afghanistani people to distinguish them from the other ethnic group. Most Hazaras have broad faces with flat noses and narrow eyes, scant facial hair, and are shorter and smaller in build then the other ethnic groups in Afghanistan. The reason for that is the malnutrition. The Hazara people who grew up in the city and foreign countries are of an average build.

Scholars differ on theories concerning the ethnic origin of the Hazaras. The theory of the autochtonicity which Hazaras have been the inhabitant of the area is supported by J.P. Ferrier. Paradigm J.P. Ferrier sustains that Hazaras have been living in the region from time of immemorial $(1857,221)$. According to him, Hazaras lived in the region even in the era of Alexander the Great. As proof of his theory, he mentions battle accounts by the Quintus Curtius, a Greek historian, and an expeditionist of Alexander in the central Afghanistan. He inquires about establishing that the people who mentioned on the battle were the forefather of the inhabitant of the region. Abdul Hay Habibi, Afghanistani scholars, also supported Ferrier's theory. Based on Hazara tradition and physiognomy, H. W. Bellew claims that Hazaras are direct descendants of the Mongolian soldiers who came to Afghanistan with Genghis Khan's expedition army. The Mongol Descendant Theory has been further supported by scholars such as Burnes, Fraser-Tytler, and certain Afghanistani scholars such as Sayed Jamaluddin Al-Afghani. E.F. Sehurmann argues that Hazaras are a mixture of Mongolians and Turks who settled in the area during the later half of the 13th century and had 
gradually been assimilated into the local population. In a similar vein L. Temirkhanov maintains that:

The Hazaras are the descendants of the intermarriage of Mongol soldiers and the dominant native groups, the Tajiks, the Turks who had inhabited Afghanistan before the Mongol invasion and to some extent, the Pashtuns or Afghans and possibly Indo-Iranians, through not to the extent of Mongols and Tajiks.

The aforementioned theories bear conceptual limitations-one-dimensionality. Autochthonicity bases its study on the relationship between sound and words in illumination of the subject matter originate a deceptive conclusion. The theory that Hazaras are not only the Mongolian origins has its own various sources as it bases on assumption of the grounds that the history of the Hazaras doesn't predate that of the Mongols. Scholar, such as Klaus Ferdinand, contradicts to this; $\mathrm{He}$ concludes that Hazara are not only of Moguls origin alone, but rather of Turko-Mogul. A Mixed Race Theory seems to provide a reasonable understanding of the historical background of the Hazaras, albeit it's conceptual ambiguity and generalization. This theory has supported by Afghanistani scholar, Sayed Asker Mousavi, who concludes, "Hazara emerged as a mixed people from the integration of several races and cultures such as the Turks, the Moghols, the Persians, the Arabs, The Afghans, and so on." He also states that the Farsi spoken by Hazaras in Heart and Mashhad has a clear resemblance to that spoken by the original natives of the area to the TurkoMoghols (Mosavi 29). Another advocate of this theory is M. H. Kakar. He believes that Hazara are a mixed race of Moghols, Turks, Tajiks and other who evolved into a new ethnic group and came to be known as Hazara between $13^{\text {th }}$ and $16^{\text {th }}$ centuries, and are in fact one of the nations' earliest original groups. He opposes to the theory that Hazaras are purely Moguls or Turk (Kakar: 1-2). Another proponents of this theory is Marek Gawecki, who states, "reassuming the hypotheses of the mixed origin of contemporary Hazara seems feasible, since these concrete, convincing facts" (1980: 165-6). Hazara is the status of Afghanistan's true oldest and one and only indigenous inhabitants.

The name Hazara has been interpreted in a different way by different people. The pervasive interpretation used to be that the word owes its origin to the Persian word, 'Hazar', meaning 'one thousand'. 'Hazar' also indicate the one-time existence of one thousand rivers, creeks and mountains in the Hazarajat. One other interpretation is thought that the word originated from the fact that Hazaras provided one thousand soldiers to central governments of the time instead of paying taxes. Leading Islamic tradition preserves that prior to the emergence of Islam there were one thousand statues in the Hazarajat which had been substitute by one thousand mosques after the overture of Islam and the spread of Islamic teaching in the region.

Islam was first introduced directly to the Hazarajat by Asad, Arab Muslim commodore, in $724 \mathrm{AD}$ (Ghobar: 71). According to Vambery, Hazara adopted Shi'ism at the time of Shah Abbas Safid where they are forced to accept Shi'ism (1864: 132). Furthermore, Schurmann proposed a similar theory, "Shi' ism could only have been introduced into the Hazarajat from the west, from Persia, the only important Shi'ite nation in the Muslim world. Hazara Shi' ism, like that of Persia, is IsnaAshari (Twelver)." He further explains that "there are no differences between Persian and Hazara Shi' ism." The history of Shi' ite is as old as Islam itself and it was not until the rise of the Safavids (16th century) that Persia were completely shi'ized and Shia become the state religious (1962: 120). 
The Shiites split after the death of Imam Jafar Sadiq in 765. Those people who followed Jafar's oldest son, Ismail, are known as Ismailis, and those who are believers of Jafar's other son, Musa alKazim, are known as Isna-Ashari. They believe in the 12 Shiite Imam Genealogy and their last Imam Mehdi disappeared about 873 and they consider the messianic ideal that he will return to rule the earth. As a subjugated minority within the Islamic world the Shiites upheld the belief that justice would prevail if descendants of Prophet Muhammad Mehdi will lead the Islamic world. Ismailis uphold that the Imamate continues until the present day, where Karim Aga Khan, an advocate and practitioner of Third World development, is the present 49th Imam of this sect. The majority of Hazara practices Isna-Ashari where else a smaller sect practice Ismailis sect of Shi'a. The spread of Ismailis started in 940 AD from Iran into Afghanistan (Habib, 1988: 874). After $1052 \mathrm{AD}$, Ismalism was practiced vividly in Balkh by the scholar and poet, Nassir Khosrou. As a result of a subsequent dream he had in Jauzjan, Nassir Khosrow went on a pilgrimage to Mecca which lasted sever years. Because of his dedication to Ismailism, he was given the status of Hojjat (Minister) by the Ismaili religious leadership, Fatimid Caliph al Muntansir (1036-94), and sent to Khorasan for the promotion of Ismailism. However, he was renounced by the Sunni clergy as a Shi'a and was forced into exile by the Saljuqi rulers of that time (Taqizadah, 1928-88: 26-37). Furthermore a small part of the Hazara population also practices the Sunni doctrine of Islam. Some of these Hazaras had been coerced to convert to Sunnism while others may have willfully or unwillingly accepted it, believing that by their conversion into the dominant faith they would enjoy more security and stability and escape religion-political persecution. Although there are no crucial differences between Shi'a and Sunni, but that has not stood out in reality, where the coexistence of the two sects has led to bloody wars that each sect is undermining the other for its benefit of its political arena and materialization of new political limitations.

Hazaras have enjoyed independent status since their formation as an ethnic community. They were surrounded by hostile nations trying to subjugate them and incorporate their land into their kingdoms. A number of rulers of the neighboring countries had succeeded in occupying several villages in the periphery of the Hazarajat and compelled the Hazaras to pay taxes. For the most part Hazarajat remained independent until the early 19 th century. The total Hazara population is estimated to be between 6 and 7 million. Considering the population figure for 1990 in seven provinces of Afghanistan that estimates Hazara population at 2,060,014. Hazaras constitute 20 per cent of the population in Kabul, 18 per cent in Parwan, 40 per cent in Wardak and 80 per cent of the population in the Bamiyan, Ghor, Uruzgan, and Ghazni provinces. This information totally contradict to the population Hazara estimated in Kabul in early 1990s to be more than half of the population of Kabul. Table 1 also shows Hazara populations in seven provinces in 1990. Contrary to population around the seven province, Table 1 does exclude Hazaras whom has had settled in Heart, Qandahar, Balkh, Andarab, Khenjan, Taliqan, Nemakab, Nahrin, Tugai, Chashma, Chal Ishkamish, Derain, Teshkan, Shahr-e-Buzurg and Rustag. Currently the total population of the Hazaras may reach between 5 and 6 million. 
Hazaras population, 1990

\begin{tabular}{llll} 
Province & Population & Percentage of Hazaras & Hazara Population \\
\hline Kabul & $2,052,781$ & 20 & 410,556 \\
\hline Parwan & 488,748 & 18 & 87,975 \\
Ghor & 302,497 & 80 & 241,997 \\
Bamiyan & 301,530 & 80 & 241,224 \\
Ghazni & 700,794 & 80 & 560,635 \\
Uruzgan & 460,932 & 80 & 368,746 \\
Wardak & 372,202 & 40 & 148,881 \\
Total & & & $2,060,014$
\end{tabular}

Source: Afghan Jehad, Vol 4, No 2 (January - March 1991) p 1

\section{Social Stratification}

In Hazara society, Tol is made up of several families, where a family is considered a $d o o d$, and Tol is also called Tolwar or Tolwarah. Every Tol has its own chief who represents the families in his Tol so he is known as Malik; however, he has no official position but he is the head of one of the families where he is in charge of settling family's disputes. A number of Tols make up a Tayefa, which is a more multipart than the Tol, that consists a network of social and economic relations. Each Tayefa has a chief, recognized as the Arbab or Khan, whose association with the families are through the Maliks, who in order refer any problems back to the Arbab or Khan. The Arbab or Khan is usually affluent figure who benefits from a high socio-economic status. Mr. Mousavi further explains that:

The highest unit in the social hierarchy of the Hazaras is the Qaum, made up of a conglomeration of several Tayefas. Qaum is a more complex network of relations that the Tol or Tayefas, covering political, social, economic, military and cultural relations. (1997: 46)

During the post-Moghol era that lasted from 1200 to 1890 AD was the most unstable and destructive time for the Hazaras. First they were assaulted by Moghols and shortly after by Timurids which brought the disintegration of Hazara society. Bamiyan, the center of Hazarajat, was totally destroyed, never to recover its pre-Moghol magnificence. Hazara society remained decentralized and backward for many centuries in the making. During these seven centuries the social and economic structure of Hazara society was made up of landed nobilities (feudal), peasants and artisans. Feudal landowners of various sections were situated at the top of the Hazaras social ladder. The Hazara edict classes were known by their own titles, such as Mir, Khan and Sultan, which at the same time were chiefs of their tribes. Hazaras lower social classes include peasants, artisans, herders and small animal husbandry belonging to various tribes and societies.

Relationships between the ruling and the ruled social classes were based on ownership of the means of vast production such as animals and agriculture (Harlan, 1939: 124). 
The Hazara ruling class maintained their titles that either had been chosen by them or had been granted to them by chiefs of neighboring societies. The title 'Mir', which means chief or leader, was bestowed upon the most important and influential Hazara chiefs of Behsud, Daizangi and Daikundi. Mirs often married several women in order to have more children and therefore gain more societal status. A Mir's wife was known by the title, 'Agha' and if she belonged to the same social class as her husband she could play a major role in the sociopolitical affairs of that area. In public she often sat next to her husband, wore men's clothes and carried arms.

The following is and outline of distribution pattern of land among the Hazaras:

(a) land owned by the Mirs;

(b) land given as a reward by the Mir to his servants and soldiers, known as jagir. (There were also two types of jagir: one which was passed on to descendants after the death of the Mirs 's servants; and another which was handed back to the Mir after the servants's death);

(c) land belonging to Hazara peasants;

(d) land used by all members of the tribe as pasture and grazing ground known as 'common property';

(e) endowed land (Temirkhanov, 1980: 65).

The division of territory did not necessarily limit the Mir's over all control. The Mir had the rights over all these properties such as the rights that gave him legal control and allow him to treat his servants and peasants in any manner that he deemed so. Tribal association among Hazaras of lower social classes rarely constituted the basis of their social relations, because socioeconomic and political changes in the 19th and 20th centuries which had greatly affected Hazaras social relations. The Hazaras subsequent migrated within and outside of country. This contributed, to some degree, to the detribalization process of the society.

Political and military influence remained an exclusive control of the Hazara landed gentry. In 1830 Hazara chiefs had their own regular-armed men. Mir Sadiq Beg of Sarjangala 900 regular-armed men and 800-foot soldiers, and Muhammad Mir Daizanjat 1,000 and Mir Yazdan Bakhsh of Behsud had 2,000 armed men. Hazara chiefs in Jaghori could have mobilized 5,000-armed men, and those of Sangi Takht and Miran, each had 400 armed men and were able to mobilize 1,000 men. The chiefs of that area collected taxes from the peasantry with the aid of their paramilitary clique. The preeminence of the chiefs had been legitimized by clerics who issued religious edicts in their favor. Most clerics were on the payroll of Hazara chiefs and later become owners of gifted land and received religious taxes. Clerics were also occupied important administrative posts or presided over judicial and legal matters. Relations between the Hazara ruling class and Afghan monarchies were based on the principle of ordinary cooperation. The Mir was expected to pay annual taxes to the king for assuring the security of trade routes within his territory. He was also obligated to send a member of his family to lead a group of armed men to serve the king in times of war and societal crises, and the king shared by conceding Hazara chiefs the right to exercise political power in their respective regions.

Hazaras lost their sovereignty when the British-supported King Abdur Rahman Khan (1880-1901) defeated the Hazara tribes one by one, occupied the whole Hazarajat and integrated it into the 
Afghan state in 1893. To protect its interests in the Indian sub-continent the British motivation was to create a strong central government in Kabul. For this reason they supported Abdur Rahman in the subjugation of national societies throughout the country especially the Hazaras. To rally public opinion in support of his war against Hazaras, Abdur Rahman encouraged religious leaders to travel to villages and allure people into a jihad (religious war) against Hazaras. Abdur Rahman vindicated his vicious war on Hazaras on the grounds of religious crusade and considered Shi'a as godless infidels. Abdur Rahman fought in the name of religion twice: "once against the Hazaras because they were Shi'a, and another against the Nuristanis, whom he considered altogether pagan" (Mousavi: 1997: 114). In order to propagate his crusade Abdur Rahma called upon his Pashtun people:

All those who have rebelled against me, the Amir of Islam, must be annihilated. Their heads shall be mine; you may have their fortunes and children. (Faiz, 1912, Vol. 3: 809, 812)

Hazaras did not want to become an easy prey for Abdur Rahman's army; they fought until they got defeated very severely. Even after the war was over, like other national society, they were willing to help enemies of the Kabul rulers. Since their defeat in 1893 Hazaras have been enslaved and subjected from much worse discrimination and oppression, which I am going to discuss that on a separate article.

Abdur Rahman devided Hazarajat into several existing provinces. His main objection was to abolish once and for all, the Hazara's sense of unity and sovereignty and to create a division within the Hazara society. By restraining Hazara people Abdur Rahman's intention was to teach a lesson to other ethnic society that they will experience a similar doom if they attempt to insurgent against his decree. Furthermore he want to pave the road for the succession of his son after his death as well as to provide state officials a better means of maintaining state vigilance on Hazaras, where he collected taxes from all areas of Hazarajat and enslaving them if they could not afford to pay taxes. For this, Abdur Rahman reminded his subjects to be thankful to him for enslaving Hazaras with this idiom: 'if there were no Hazaras, the price of donkeys would be very high'. One of the legacies that Abur Rahman left, it was possibly this idiom:

It is a saying in Afghanistan they would have to work like donkeys if it were not that the slaving donkeys of Hazaras do all the work for them. (Sultan, 1980: 277)

Furthermore, another anecdote which reflects the social and economic misery of the Hazaras is the bridge currently known as Pul-e Nadir Khan. There are saying among Hazaras in Oruzgan, Bamiyan, Behsud, Jaghouri, and even in Pakistan that this bridge used to be called a Pul-e Yak Paisagi, because Hazara Mirs sold slaves one paisa each $(100$ paisa $=1$ rupee $)$ and the money were spent to build that bridge. Even Sultan who was a court writer of The Life of Abdur Rahaman in the 1980 s made a note about the poverty and social status of the Hazaras:

All the hardest, dirtiest, and most menial work is done by the laboring classes of the Hazaras, and there is scarcely a house without its Hazara servant, in the form of slaves, stablemen, etc. (ibid.: 77) 
Abdur Rahman further detribalized the Hazara society by sending Sunni clerics to every village in Hazarajat to coerce Shi'ite Hazaras to attend Sunni mosques, so they would abandon Shi'ism. Furthermore, he imposed tougher regulations on Hazaras by confiscating land and forcing them to pay heavy taxes. On April 11, 1894, Abdur Rahman ordered to seize all grazing land in the Hazarajat, with the condition that under no circumstances the Hazaras should be allowed to graze their own lands any longer (Faiz, 1912 Vol. 3: 855, 986-7, 1159) and consequently transforming farming land into grazing land (Mousavi, 1997: 134). Besides confiscating and using Hazara's land for the benefit of his own ethnic group, Amir further imposed heavy taxes on the Hazara society. Sayed Asker Mousavi writes, "[the] most brutal and inhuman tax requiring mention here was the 'tax on the sale of slaves'." For instance, according to Faiz Mohammad Katib and government reports, Amir collected $268 \mathrm{Kg}$ wheat from 500 mid class families in Ajristan and the impoverished families had to pay three Afghanis. On average, the state collected 60,000 to 70,000 rupees annually from the trading of slaves and forced the Hazara girls into marriage in Daya Fulad, Zawuli and Sepai districts. In the Shikh Ali district, an estimated 7,000 cattle were taken and 350 men and women of the Jaghori district had been sold at Kabul markets each at the price of 20-21 Afghanis (Faiz, 1912, Vol. 3: 969, 989, 1107, 1116, 1132, 1226-28). Abdur Rahman's brutal suppression forced a large number of Hazaras to seek refuge in Iran, Pakistan and Russia. The only way that Abdur Rehman could have succeed in subjugating Hazaras and conquering their land was when he effectively utilized internal differences within the Hazara society, appointing sold-out Hazara chiefs into his bureaucratic sales of the enslaved Hazara men, women and children after 1897. The Hazaras remained de facto slaves until the King Amanullah Khan declared Afghanistan's independence in 1919. The reason that most Hazara appreciate him is because he was the one who abolished slavery and made it in to the Afghanistan's Constitution.

\section{Hazaras in the Post Independence Period}

Amanullah had a characteristic of bourgeois development where he tried to modernize Afghanistan based on a European model of advancement. As Sayed Asker Mousavi puts it, "although not ruthless like his grandfather, Abdur Rahman, and apparently liberal, Amanullah was equally ethnocentric in his role." During his reign the foundation of Afghan nationalism were placed. Amanullah's successor, Nadir Shah, misguided his whole notion of changing Afghanistan from a 'tribal' society to a 'national' society. It is misguided, because Nadir Shah and later Zahir Shah, Afghanistan's last two kings, materialized it to 'Pashtunization of Afghnistan.' The insinuation of this 'Afghan nationalism' for the Hazaras during the $19^{\text {th }}$ century has been very significant in economic, political, and cultural underdevelopment, where they had been provoked by cruel social isolation and deprivation. The Hazaras response and vengeance in the face of such discrimination has been resistance (1997: 156). In 1923 Amanullah Khan initiated a new constitution which abolished slavery and granted equality to every citizen of the country. When pro-British King Habibullah overthrew Amanullah in 1929, Hazaras supported him and fought to restore his throne. After nine months of rule, Habibullah was captured by Muhammad Nadir Shah and executed. Although Nadir promised that he would restore Amanullah to the throne, but later he declared himself the new king. While simultaneously condemning Hazara's culture and history Nadir's government appointed Pashtun administrators to Hazarajat and tried to build Pashtun nationalism by promoting the Pashtu language and popularizing its culture in Hazarajat. Hazaras saw the materialization and enforcement of Afghan, or correctly Pashtun, nationalism under the reign of the 
Muhammadzai family. The whole purpose of transformation was to eliminate the regional and colloquial language and advocate Pashto in the national and official language of Afghanistan:

The administration of Pashto courses, from now on, is carried out by the Ministry of Education. In Kabul alone, some 450 Pashto courses have established; all government and other public officials are required to attend said courses in order to learn their national language. (Gharghasht, 1966: 44-5; also see Pstruskinska, 1990: 33)

Mahmud Tarzi, the foremost figure among erudite modernists in favour of a constitutional monarchy, introduced this new idea of Afghan or Pashtun nationalism and he had a strong belief in the notion that Afghanistan must have its own distinct language in order to maintain its liberty and sovereignty, especially from its neighbor, Iran. In 1914 he wrote:

Now it becomes necessary to address ourselves, on the importance of national language Pashto...Firstly, we should understand that every nation has a national language which gives it its life. A nation which loses its language also loses its life. The protection of the basic language of every country is as important as the protection of its life. We are called Afghan Nation and our beloved homeland is called Afghanistan. We possess specific customs, ethics and a national language and attempt to develop and improve it. Every citizen of Afghanistan must learn this language even though they may not be a Pashto speaker, and our schools must make the teaching of this language their most important vocation. (Mousavi, 1997: 157-158; also see Pstrusinska, 1990: 26-36)

Farsi had been and continued to be the historical language of the majority of Afghanistan's population. Nevertheless, since it was spoken in Tajikistan and Iran, the Muhammadzai rulers carry out along with the help of Mahmud Tarzi and declared 'Pashto' the national language of Afghanistan:

It is the duty of the State to prepare and implement an effective programme for the development and strengthening of the national language, Pashtu. (Griffiths, 1967: 154)

Therefore, not only did Pashto fail to replace Farsi among Farsi-speaker, but it also failed to institute itself as the language of many Pashto-speakers. The lack of enthusiasm among the people in general and especially the Pashtun who had migrated to the cities and abandoning Pashto in favor of the more established Farsi as their language that caused the failure of Pashto becoming the lingua franca of Afghanistan:

A considerable number of Pashtun nomads in western Afghanistan lost their native tongue and began to use Dari [Farsi]. One of the groups is the Nurzai from Adraskan. Another example of these Dari speaking Pashtun[s] are the Mohammadzai from Kabul and the Mohammadzai from Kadahar ... Most Pashtu speakers living in urban areas learn Dari for practical reasons, business, education etc. and its role as lingua franca. (Pstrusinska, 1990: 30) 
The inability of implementing Pashto as the official language of the country forced the policy maker to abandon their costly programme demonstrated a barrier for the process of Afghanistan to achieve a unified political, economic and social development (Mousavi, 1997: 158-9).

In addition, the Hazaras, as Farsi speakers, were suppressed severely during this period where they were faced systematic denial of their culture and history. Furthermore, it was forbidden to praise the history of the Hazaras. Policies were designed to obliterate historical names from state archives that had been associated with Hazaras. Nadir Shah executed, incarcerated and harassed Hazara intellectuals who were articulating Hazaras culture and history. Although Hazaras were enlisted into the army and employed in civil service departments, but they were not promoted beyond the rank of colonels in the army and directors in public offices. As a result, Nadir effectively incapacitated Hazaras authority. He also tried to occupy and deprive them of their fundamental rights, allowing Pashtun nomads to gradually absorb Hazaras land. According to Hagshinas, approximately one-third of the Pakistani Pashtuns were settled throughout Afghanistan and a very large number settled in Hazarajat from 1930s to the 1970s (1984: 380). Furthermore, an assassination campaign against leading Hazara and Shi'a figures carried out under the order of Nadir Shah where Shahzad Khan, a Kahn of Solaiman Khil clan, claimed that:

This year I had the time and opportunity to kill only one Hazara, Najaf Beg. For we had received orders by Nader Baba [Nadir Shah (1929-33)], to kill as many leading Hazaras as possible, so that their lands can be confiscated and distributed among us. (Talib, 1983: 29)

Hazaras had always looked up to Hazara intellectuals in the Indian sub-continent as a source of encouragement. In order to divest Hazaras of their leadership and prevent their solidarity in the international arena, Nadir Shah attempted to allure Hazara intellectuals into Afghanistan, promising lucrative employment, and then restricting their social and political activities. For instance, Nadir Shah invited a well-known Hazara army officer, Ali Dost Khan of India, to visit Afghanistan and appointed him an army colonel in the Afghan armed forces. Although Ali Dost was dismayed with Nadir's policy, and he could not return to India, so he reconciled himself to a life in Kabul where he was kept under state surveillance.

The Kabul government pursued more severe policies aiming at further Pashtunization of every aspect of life in the nation, causing Hazaras to seek uprising against the state. The ruling class within the state administration ordered the standing army to crush the insurgence, which led to the arrest and execution of well-known Hazara leaders. Table II consists the names of many leading Hazaras and Shi' as who have been imprisoned for life, many have died while detained or murdered under false pretexts conspicuously. Hazaras people again organized an armed rebellion in opposition to the aggravation of heavy taxes in the late 1950s. The state appeased the resistance by revoking taxes impose on Hazaras and imprisoned the leaders of the rebellion, including, Muhammad Ebrahim Beg, known as Bache-e-Gaw Sawar, Khawja Naeem and Sayed Muhammad Esmail Balkhi. Ebrahim conciliated his main beliefs and later released from jail while Balkhi detained until 1964. 
Table II

\begin{tabular}{|c|c|c|c|}
\hline Name & Postion & Sentence & Date \\
\hline Gholam Nabi Chappa Shakh & Socio-political leader & Death/executed & $N / A^{*}$ \\
\hline Dr. Barat Ali Taj & Economist & Life/died in prison & $"$ \\
\hline Sayed Ali Asghar Sho'a & Writer/scholar & $"$ & $"$ \\
\hline Gholam Sarwar Joya & $"$ & $"$ & $"$ \\
\hline Akhond Mirza Hossain & Religious leader & Death/poisoned & $"$ \\
\hline Mulla Khodadad Loroka & Religious leader & Death/executed & $"$ \\
\hline Mindi Khan Qizilbash & Socio-political leader & " & $"$ \\
\hline Fatih Mohammad Khan & $"$ & Life/freed after 18 years & $"$ \\
\hline Allama S. M. Isma'il Balkhi & $"$ & Life/freed after 14 years & 1964 \\
\hline Sayed Ali Gauhar Ghurbandi & $"$ & " & 1964 \\
\hline Sayed Isma'il Lolinji & $"$ & $"$ & 1964 \\
\hline Sons of Masjidi Khan Ghaznawi & $"$ & $"$ & 1964 \\
\hline M. Aslam Sharifi Ghaznawi & $"$ & $"$ & 1964 \\
\hline Abdul Latif Hirawi & $"$ & $"$ & 1964 \\
\hline Mohammad ibrahim (Gaw Sawar) & $"$ & $"$ & 1964 \\
\hline Ayatullah S. M. Sarwar Va'iz & Religious leader & Freed after 4 years & $"$ \\
\hline Ayatullah Mohsini & " & Freed after 4 years & $"$ \\
\hline Hojjatul Islam S. Shah Abdul Azim & $"$ & " & $"$ \\
\hline
\end{tabular}

*N/A=not available; Source: "The Hazaras of Afghanistan" by Sayed Askar Mousavi. Page 165

To eradicate the Hazara people of their ethnic identity and consolidate Pashtun domination, the ruling circle in the Afghan polity, influenced by the Nazi ideology and the rise of Germany as a major world power, continued the Pashtunization of every aspect of non-Pashtun ethnic society. They initiated the financing for publication of periodicals and literature with fabricated historical writing and documents to validate the superiority and historicity of the Pashtu language and culture. Hazara scholars maintain that publication of Puta Khana (The Hidden Treasure) in 1960 by a proestablishment scholar, Abdul Hay Habibi, is a reflection of this policy. Habibi claims that in 1142/1763 King Hussain Shah Hotaki ordered Muhammad Horak to compile a profile of Pashtun heroes and models of their literary works. Puta Khana chronicles the life story of Pashtun heroes and their literary works dated a hundred years after the death of Prophet Muhammad.

This trend of development led pro-establishment scholars to assume that many cities with Hazara names have had originated from Pashto. For instance, Ler Wand, a village in Ghor, assumed to originate from the Pashto words Lar (road) and Wand (block). Similarly, Aspi Buz district in Ghor owes its origin to the Pashto word, Spin (white) and Buz (goat), and Surkh Ghar (Red Cave) is an alteration of the Pashto words Ghar (mountain). The process of Pashtunization was dynamically pursued in the areas where Hazaras had been settled among other ethnic groups, and also because their greater tolerance toward religion. Most Hazaras were affluent and wielded a certain degree of social influence and authority, which made their integration much easier. This situation was encouraging for Hazara chiefs to marry non-Hazara women in addition to their own. Pushtunization policies deprived the Diaspora Hazara of their true ethnicity by registering and 
associating them with the dominant ethnic group in that community. State coercive policies forced many Hazaras to conceal their identity when they were trying to obtain state identification cards. There were widespread held beliefs that their security depended upon silence and concealment of their ethnic identity. It is due to this factor that the younger generations of Hazaras, especially those of mixed background, are not aware of their historical and ethnic identity, where they have the notion which they are not Hazaras. State policies regarding registering Hazaras of mixed background, as non-Hazaras were intended to further annihilate Hazaras social and ethnic identity.

In order to marginalize the Hazaras role in politics the ruling class partitioned Hazarajat into these five provinces: Bamiyan, Ghazni, Ghor, Uruzgan and Wardak. Again the state intended to eliminate the collective bargaining power of the society and to emasculate their political might. By partitioning Hazarajat, the state also intended to deprive the region from international aid allocated for its improvement and also to minimize the number of Hazaras political representation (on the basis of majority of votes) in the Woolusi Jirga (the House of Parliament). For instance, Daikundi, With a population of 240,000 was recognized as a Wuluswali (sub-province) and Jaghori with population of 220,000 was considered as wuluswali and it is considered to be the biggest wuluswali in the whole country. Other Hazara regions in the north, such as Charkent, Kushenda, Sangcharak and Balkhab, each with an estimated 100,000 population, were designated as Alaqadari (district). Suppressions of Hazaras went hand-in-hand with the state policy of building Pashtun political domination. Until recently, the state elevated the Pashtun settled regions in the Shahr-e-Safa district, Qandahar province with a population of 3,000 , to the status of a sub province, legally qualifying it to send elected representatives to the House of Parliament. Other Pushtun settled areas, such as Alaqa Mizan in Qalat with a population of 3,500, and Haji Maidan and Shajoy each with a population of 3,000 had been named sub-provinces, so the Pushtuns in those regions would not be bereft of political representation and would receive financial support from the central government.

Along with the state consolidation and domination, the status of Hazara chiefs had been reduced to that of middleman arbitrating between states role and the Hazara peasantry. Hazara chiefs used their position to build a scheme based on economic compulsion and made a large segment of the rural population dependent through rental tenancy arrangements, lending and investing money in the local market, and manipulating the rental system and market interests. They also used a good portion of state revenues for consolidating their position and maintaining a new system of clientele. Repression by the Hazaras ruling class and steady economic competition by the Pashtun merchants and traders forced a large number of Hazaras to migrate to major cities inside and outside the country. Furthermore, the isolation caused the Hazarajat to loss its most productive sources of agricultural produce where it provided for the whole country: 'The Hazaras ... used to provide the whole of Afghanistan with meat and cooking oil' (Talib, 1983: 49). In spite of that the Hazaras suffered the most severe famine in 1970. Whereas the famine hit most of the central provinces up north, but the central provinces of Afghanistan endured the most. The under-development of the Hazarajat, its geographical isolation, and government biased improvement programs averred the lives of many Hazaras:

When drought struck the remote and mountainous central Afghanistan of Hazarajat in the early 1970,50,000-100,000 people are thought to have starved to death because emergency supplies were never sent or were unable to get through. (Arney, 1988: 8) 
The Hazaras and Their Role in Afghanistan

Hussain Nayl writes on this intended isolation of the Hazaras:

As a direct consequences of the policy of isolation of the Hazaras, in 1341 [1962] local governments throughout the Hazarajat were disbanded and instead annexed onto the neighbouring six velayats [provinces]. (Nayel, 1985: 14)

The situations of Hazaras in the post-independent period were characteristic of a pariah position which is underprivileged politically, socially, economically and culturally. They were subjected to all kinds of public humiliation and embarrassment as taunted by derogatory terms such as Hazarae-mushkur (mice-eating Hazaras), bini puchuq (flat-nose), khar-e-barkash (load-carrying donkey), etc. 